\title{
How military history can inspire medical intervention
}

\author{
Yskert von Kodolitsch ${ }^{1}$, Martin Prokoph ${ }^{2}$, Arnim Sachweh ${ }^{1}$, Tilo Kölbel ${ }^{1}$, Christian Detter ${ }^{1}$, \\ Jürgen Berger ${ }^{3}$, Thomas Wick ${ }^{4}$, Sebastian Debus ${ }^{1}$, Carl Rudolf Blankart ${ }^{5,6}$
}

${ }^{1}$ German Aorta Center Hamburg at the University Heart and Vascular Center Hamburg, Hamburg, Germany; ${ }^{2}$ German Bundeswehr, US Army Command and General Staff College, Fort Leavenworth, KS, USA; ${ }^{3}$ Department of Medical Biometry and Epidemiology, University Medical Center Hamburg-Hospital Eppendorf, Hamburg, Germany; ${ }^{4}$ Leibniz University Hannover, Institute of Applied Mathematics (IfAM), Hannover, Germany; ${ }^{5}$ KPM Center for Public Management, University of Bern, Bern, Switzerland; ${ }^{6}$ sitem-insel AG, Swiss Institute for Translational and Entrepreneurial Medicine, Bern, Switzerland

Correspondence to: Yskert von Kodolitsch, MD, MBA. University Medical Center Hamburg-Eppendorf, Hamburg, Martinistr. 52, 20246 Hamburg, Germany. Email: kodolitsch@uke.de.

Submitted Feb 06, 2020. Accepted for publication Mar 16, 2020.

doi: $10.21037 /$ cdt.2020.03.06

View this article at: http://dx.doi.org/10.21037/cdt.2020.03.06

\section{Introduction}

Our three-panel picture (Figure 1) demonstrates how contemporary observers derived a precise description of historical events from Napoleon's invasion of Russia (Figure 1A), how they translated these descriptions into military concepts (Figure $1 B$ ), and how, over centuries, these concepts have matured into general models of military intervention (Figure 1C). Today, such models serve as inspiration for high-ranking military leaders. Military and medical intervention takes place in substantially different settings and they have profoundly different objectives. Nonetheless, in this essay we show how concepts and models from military history can inspire medical intervention (Figure 1D).

\section{Military history}

On Midsummer Day 1812, Napoleon crossed the Neman River to invade Russia (Figure 1A). At that time, he was in command of the biggest army ever raised in European history. However, already a fortnight before Christmas, Napoleon's campaign reached a disastrous end. Of 422,000 soldiers, only 10,000 survived to re-cross the Neman River. Napoleon had lost his army, his glory and he was about to lose his empire. At the beginning of his campaign, Napoleon predicted sure victory, as he was only a few kilometers behind the Polish border. The Tsar's army retreated and left the French unsupplied on scorched Russian earth. Whereas the Tsar tried to avoid a decisive battle, Napoleon did everything to force it. Therefore, Napoleon chased the Russian army in a frantic race through the summer heat while his soldiers died from thirst, exhaustion, and missing supplies. On August 17, Napoleon entered Smolensk. At that time, two thirds of his army were already dead, and the remaining forces were only equal in size to the Russian army. With his depots 500 kilometers away, Napoleon's army was running out of supplies whereas the Russian army received support from their peasants. Napoleon ignored the shift of forces and pushed his army over another 400 kilometers into Moscow. On this march, Napoleon lost another 45,000 soldiers. In deserted Moscow, Napoleon waited for the Tsar to beg for peace. However, after one month of waiting in vain, the advancing winter forced Napoleon to withdraw. Napoleons army retreated over scorched roads in icy winter. During this retreat, another 90,000 soldiers died from Cossack raids, disease, hunger, and freezing (4).

\section{Moving from history to description, and further to concepts}

The Prussian General Carl von Clausewitz (1780-1831) was an eyewitness to Napoleon's Russian invasion. Clausewitz served as an advisor to the Russian army, where he gave a detailed description of the military events (3). Based on his account, the French engineer Charles Joseph Minard (17811870) drew a map to summarize the disastrous French losses during this campaign. With this famous map, Minard, for 


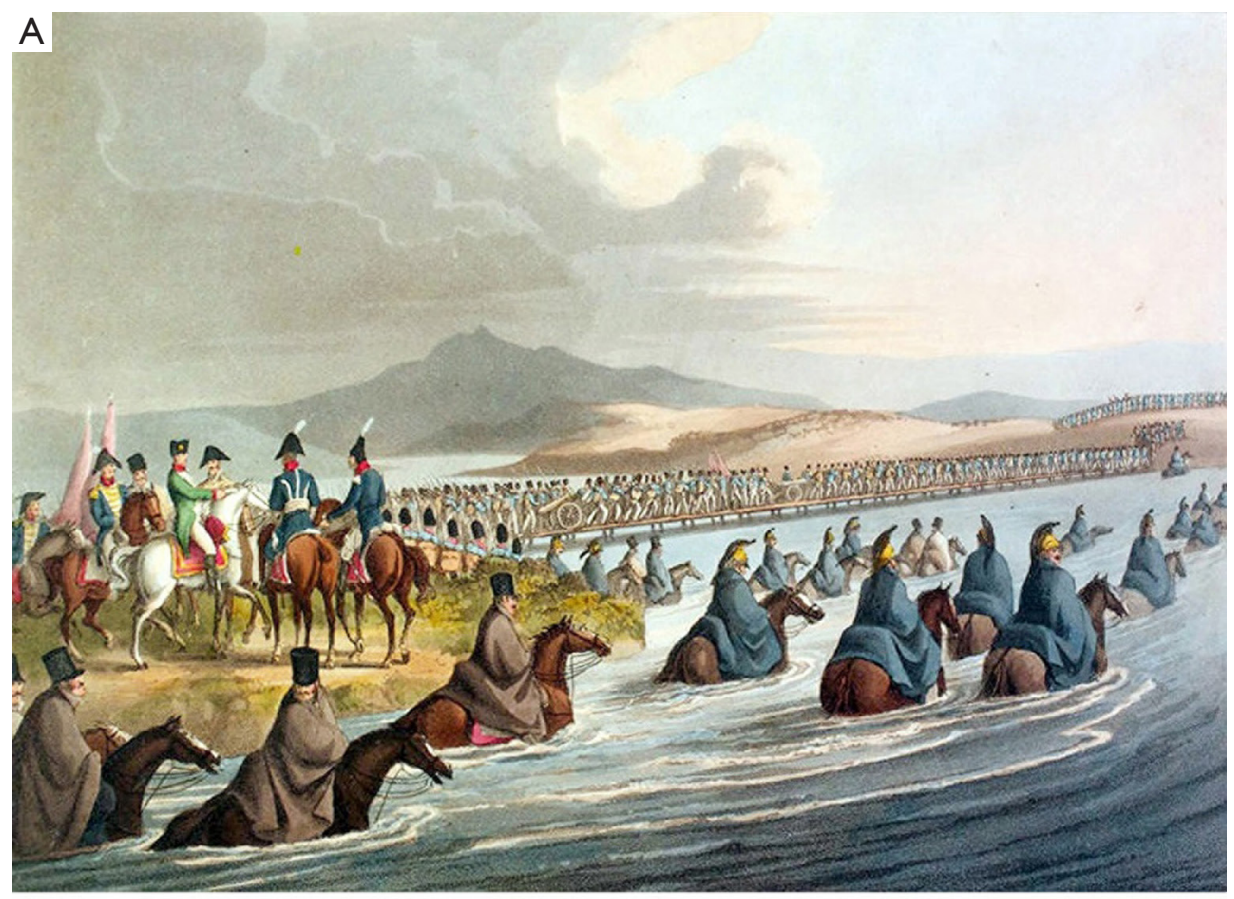

B
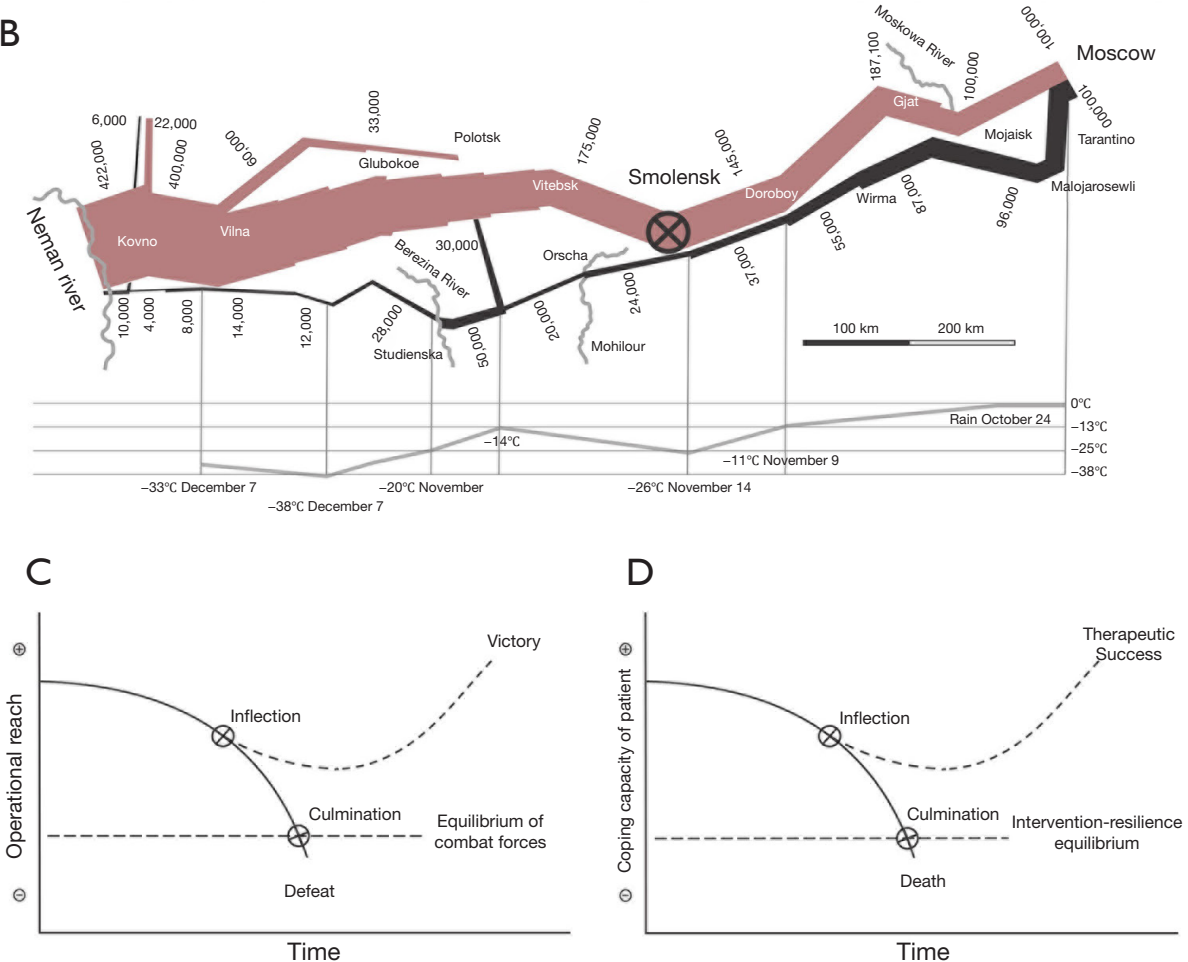

Figure 1 The evolution from history, to concepts, to models. (A) "The boasted crossing of the Neman, at the opening of the campaign in 1812, by Napoleon Bonaparte" based on a drawing by an officer, painted by John Heaviside Clark and engraved by Matthew Dubourg (1). (B) Modification of Charles Minard's 1869 chart showing the number of men in Napoleon's army in 1812 during attack (red) and retreat (grey), their movements, and the temperatures during retreat (2). The " $\mathrm{x}$ " in the circle at Smolensk marks the culmination point of the French attack (3). (C,D) The curves of military attack (C), and medical intervention (D). 
the first time in the history of statistics, depicted the scale of disaster. On the same map, he visualized how Napoleon sacrificed thousands of human lives during retreat in a hopeless race against declining temperatures of the Russian winter (Figure 1B) (5).

Clausewitz moved from the description of the Russian campaign to the discovery of a key concept, which he named the "culminating point of attack". Clausewitz reasoned that Napoleon's attack on Russia required a force that was superior to the force of the Russian defense. Napoleon's attack weakened through casualties, increasing distances to supply bases, and the need to defend their conquered ground. Clausewitz concluded that attack culminated where its force was equal to the force of defense. At this culminating point of attack, Clausewitz reasoned that attack had to revert to defense. If instead, the attack "overshoots culmination", the force of defense will gain the upper hand, with defeat of the attacker as a necessary consequence (6). According to Clausewitz' analysis, Napoleon reached culmination in Smolensk (Figure 1B). Here, Napoleon should have stopped the attack to avoid his own predictable defeat (3). Clausewitz mentioned two major reasons why military leaders overshoot the culminating point. First, the attacker's psychology makes it less difficult to go on than to stop (7), where lack of self-criticism, stubbornness, and over-ambition may be additional contributing factors. Second, the attacker's mind may ignore culmination because of missing or distorted information, a phenomenon that Clausewitz captured in his concept of friction. Today this concept is better known as the "fog of war" (8).

\section{Moving from concepts to models}

\section{Military attack}

Milan Vego, as author of a today's standard textbook on operational warfare, used Clausewitz' concept of culmination to derive a prototypic curve of military attack. In this curve he depicted the gradual decline of actual combat power during attack (9). To describe the attacker's actual combat power, the U.S. army defines operational reach $(\mathrm{OR})$ as the distance and duration across which the attacker is able to employ his combat power. To model Vego's curve as mathematical function, we define operational reach as the difference of the attacker's combat power $\mathrm{P}$ minus his combat efforts $\mathrm{E}$ (comprising offensive and defensive actions), resulting in a basic equation of military attack: $\mathrm{OR}=\mathrm{P}(\mathrm{t})-\mathrm{E}(\mathrm{t})$, where " $\mathrm{t}$ " stands for time. Clausewitz' culminating point is where the attackers' and the defenders' operational reach are at equilibrium. When the attacker continues to advance after culmination, defeat is the attack's most likely result. For victory, the attacker needs to reach an inflection point where the direction of the function curve turns from decline to increase of operational reach. Usually inflection takes place when the attacker attains military advantages. The attacker can increase his combat power, e.g., by exploiting resources of conquered ground, drafting more troops, by reverting from attack to defense, or because of a substantial decline of the defender's resistance. For a certain victory, attack should reach inflection well ahead of culmination (Figure 1C).

\section{Medical intervention}

Similar to a military attack, surgery or percutaneous intervention initially leads to a deterioration of the patient's condition. Let us consider the actual health status as coping capacity of a patient CCP, and let us suppose that this equals the difference between resilience $\mathrm{R}$ and disease $\mathrm{D}$, which is $C C P=R(t)-D(t)$, where " $t$ " stands for time. Similar to a military attack, the initial phase of an intervention reduces the coping capacity by reducing resilience without reducing disease burden. Consider, for example, coronary artery bypass surgery, where narcotics, sternotomy, preparation of bypass vessels, and extracorporeal circulation reduce physical resilience. At some point, the decline in resilience can reach a threshold beyond which the patient's resilience collapses, with death as a likely result. This point corresponds to the culmination of a military attack. A successful intervention needs inflection of the curve from decrease to increase of coping capacity. Usually inflection takes place through treatment of the disease. In bypass surgery, the aim of therapy is to reduce coronary artery disease. Heart surgeons reduce adverse myocardial effects by using a coronary bypass. However, to maximize coping capacity, intervention has two options: to reduce disease, or to increase resilience. Therefore, after inflection, it becomes possible to increase resilience by weaning the patient from heart-lung bypass, ending mechanical ventilation, and by closing the sternum. Early mobilization, breathing exercises, and rehabilitation will bring the full exploit of the intervention with additional gains of coping capacity. Similar to a military intervention, medical intervention should reach inflection far before culmination (Figure 1D). 


\section{Discussion}

At the level of concrete events, military history and medical intervention lack similarity. At the level of concepts and models, both disciplines can share insights nonetheless. Mutual learning of military and medicine goes back to ancient history. As a prime example, the Greek general and historian Thucydides applied the medical concept of prognosis based on causal understanding of human nature in his famous analysis of the Peloponnesian war, to predict the course of historical events. He derived his concept from Hippocrates, who at Thucydides times was a celebrated founder of a new, "science-based" medicine (10).

The first question is whether there is empirical evidence for our assumption of non-linear dynamics. Minard's graphical mapping of the numbers of French troops according to time and space suggests non-linear decline of combat power during attack. Since then, such a nonlinear decline of combat power was corroborated in many military campaigns (11). In medicine, there is evidence for non-linear behavior of disease, treatment, and resilience. First, untreated disease exhibits non-linear growth, as is well-documented for growth of bacterial populations (12), pancemic spread such as COVID-19 (13), and growth of tumor mass (14). Second, non-linearity of a disease response to therapy is shown for bacterial inactivation through antibiotics (15), and for tumor shrinkage through radiation and chemotherapy (16). Finally, researchers define physical resilience as the ability to resist or recover from functional decline following a health stressor, such as infection, surgery, fracture, bed rest, or chemotherapy (17). Only just recently the emergence of novel analytical tools for estimating resilience appears to suggest non-linear response of physical resilience to disease and medical intervention (18).

Another question is whether the crossing of concepts between disciplines is just an intellectual game or whether it has a distinct value. With respect to military practice, history provided abundant proof of the value of the concept of culmination. It is unquestioned, that military leaders who avoided culmination prevented losses, whereas leaders who overreached culmination caused thousands of unnecessary deaths (11). How about medicine? The numbers of preventable deaths may be similar to those of today's military conflicts or "roughly equivalent to the number of lives lost if a fully loaded jumbo jet crashed each day" (19). The exact numbers, the spectrum and the causes of medical errors and preventable deaths in medicine remain to be specified (20). However, it is undisputed, that many unnecessary deaths relate to intervention, where interventional overreach as well as underreach may play important roles (21). In line with our findings, the "choosing wisely" campaign of the American Board of Internal Medicine made obvious the dilemma between killing a patient because of doing too much, versus killing a patient because of doing too little (22).

Concepts of culmination can be useful in medical education to clarify the key rules of intervention. For example, to maximize coping capacity, intervention must hasten inflection and delay culmination. In coronary surgery, measures to hasten inflection may be to increase resilience by myocardial reperfusion, to minimize the goal of intervention by vascularizing only important coronaries, or to split the goal by using percutaneous techniques postoperatively for less important coronary arteries. Once it becomes clear that inflection is impossible, termination of the intervention is usually the consequence. When intervention approaches culmination, it is imperative to take measures to increase resilience. A decision to perform major surgery or extensive percutaneous intervention is justified only with the clear prospect of high gains in coping capacity. Besides such key rules, our model clarifies, even to novices, the hazards of interventional psychology: Napoleon was a military genius but he overreached because he found it more difficult to stop the attack than to go on.

As with Clausewitz" "fog of war", it is one issue to know about the point of inflection or culmination, but it is another to identify such points (23). Today, during intervention, there may be monitoring of body temperature, heart rate, ECG, blood pressure, gas saturation, radiation dose, and use of contrast agents. However, these variables inform only insufficiently about the patients' actual resilience and disease status. Therefore, the advance of culmination may not become apparent early and clearly enough. Future interdisciplinary studies using mathematical modeling with the identification of key variables of resilience and disease may support timely prediction of turning points during medical intervention.

\section{Acknowledgments}

We wish to thank Michael Schlüter, PhD, Peter N. Robinson. MD, PhD, Olliver Pfenning, PhD, Karsten König, $\mathrm{PhD}$, and Walter Fiedler, MD, for their thoughtful advice on the manuscript.

Funding: None. 


\section{Footnote}

Provenance and Peer Review: This article was commissioned by the editorial office for the series "Arts and Medicine" published in Cardiovascular Diagnosis and Treatment. This article did not undergo external peer review.

Conflicts of Interest: All authors have completed the ICMJE uniform disclosure form (available at http:// dx.doi.org/10.21037/cdt.2020.03.06). The series "Arts and Medicine" was commissioned by the editorial office without any funding or sponsorship. YvK serves as the unpaid editorial board member of Cardiovascular Diagnosis and Treatment from February 2018 to January 2020. The authors have no other conflicts of interest to declare.

Ethical Statement: The authors are accountable for all aspects of the work in ensuring that questions related to the accuracy or integrity of any part of the work are appropriately investigated and resolved.

Open Access Statement: This is an Open Access article distributed in accordance with the Creative Commons Attribution-NonCommercial-NoDerivs 4.0 International License (CC BY-NC-ND 4.0), which permits the noncommercial replication and distribution of the article with the strict proviso that no changes or edits are made and the original work is properly cited (including links to both the formal publication through the relevant DOI and the license). See: https://creativecommons.org/licenses/by-nc-nd/4.0/.

\section{References}

1. Wikimedia Commons contributors, "File:Crossing the Neman in Russia 1812 by Clark.jpg," Wikimedia Commons, the free media repository. Available online: https://commons.wikimedia.org/w/index. php?title=File:Crossing_the_Neman_in_Russia_1812_by_ Clark.jpg\&oldid=331076103 (accessed March 28, 2020).

2. Wikimedia Commons contributors, "File:Minard. png," Wikimedia Commons, the free media repository. Available online: https://commons.wikimedia.org/w/index. php?title=File:Minard.png\&oldid=335068795 (accessed March 28, 2020).

3. von Clausewitz C. The Campaign of 1812 in Russia. Trans. anonymous [Wellington's friend Francis Egerton, later Lord Ellesmere], London: John Murray Publishers, 1843.

4. Mikaberidze A. H104: The Russian Campaign of 1812.
H100: Rise of the Western Way of War. US Army Command and General Staff School. Shreveport:

Louisiana State University, 2011.

5. Friendly M. Visions and Re-Visions of Charles Joseph Minard. J Educ Behav Stat 2002;27:31-51.

6. von Clausewitz C, Howard M, Paret P. The culmination point of attack. In: On War, book 7, chapter 5. Princeton, New Jersey: Princeton University Press, 1989:528.

7. von Clausewitz C, Howard M, Paret P. The culmination point of victory. In: On War, book 7, chapter 22.

Princeton, New Jersey: Princeton University Press, 1989:566-73.

8. von Clausewitz C, Howard M, Paret P. Friction of war. In: On War, book 1, chapter 7. Princeton, New Jersey: Princeton University Press, 1989:119-21.

9. Vego MN. Concept of the culmination point. In Joint Operational Warfare: Theory and Practice. Newport, Rhode Island: Naval War College, 2009:VII-73 - VII-96.

10. Swain S. Man and medicine in Thucydides. Arethusa 1994;27:303-27.

11. Milan NV. Operational overreach and the culmination point. Joint Force Quarterly 2000:99-106.

12. Zwietering MH, Jongenburger I, Rombouts FM, et al. Modeling of the bacterial growth curve. Appl Environ Microbiol 1990;56:1875-81.

13. Anderson RM, Heesterbeek H, Klinkenberg D, et al. How will country-based mitigation measures influence the course of the COVID-19 epidemic? Lancet 2020;395:931-4.

14. Gerlee P. The model muddle: in search of tumor growth laws. Cancer Res 2013;73:2407-11.

15. Grassberger C, Paganetti H. Methodologies in the modeling of combined chemo-radiation treatments. Phys Med Biol 2016;61:R344-R367.

16. Enderling H, Chaplain MAJ. Mathematical modeling of tumor growth and treatment. Curr Pharm Des 2014;20:4934-40.

17. Whitson HE, Duan-Porter W, Schmader KE, et al. Physical Resilience in Older Adults: Systematic Review and Development of an Emerging Construct. J Gerontol A Biol Sci Med Sci 2016;71:489-95.

18. Scheffer M, Bolhuis JE, Borsboom D, et al. Quantifying resilience of humans and other animals. Proc Natl Acad Sci U S A 2018;115:11883-90.

19. Leape LL. Error in medicine. JAMA. 1994;272:1851-7.

20. Bunting RF Jr, Groszkruger DP. From To Err Is Human to Improving Diagnosis in Health Care: The risk management perspective. J Healthc Risk Manag 2016;35:10-23. 
21. Leppin AL, Montori VM, Gionfriddo MR. Minimally Disruptive Medicine: A Pragmatically Comprehensive Model for Delivering Care to Patients with Multiple Chronic Conditions. Healthcare (Basel) 2015;3:50-63.

Cite this article as: von Kodolitsch Y, Prokoph M, Sachweh A, Kölbel T, Detter C, Berger J, Wick T, Debus S, Blankart CR. How military history can inspire medical intervention. Cardiovasc Diagn Ther 2020;10(6):2048-2053. doi: 10.21037/ cdt.2020.03.06
22. Fleck LM. Choosing Wisely. Camb Q Healthc Ethics 2016;25:366-76.

23. Mueller PR. The fog of war. Semin Intervent Radiol 2004;21:1-2. 